\title{
MEMBENTUK KARAKTER SISWA DENGAN MENANAMKAN NILAI-NILAI MATEMATIKA
}

\author{
Dede Salim Nahdi \\ Universitas Majalengka \\ Jl. K.H. Abdul Halim No.103 Majalengka Kulon, Kabupaten Majalengka \\ Email: salimnahdi15@gmail.com
}

\begin{abstract}
The failure of education can create products that no longer have the sensitivity of conscience based on morality, sense of humanity, and the problem of moral decadence. Lots of events that indicate the increasingly eroded moral of the nation, such as promiscuity, violence of children and adolescents, crime against friends, theft by teenager, cheating, drug abuse, and so on. That's why education should return to nature. Education is not only oriented to intellectual intelligence but also emotional intelligence. Each subject taught should help the children to grow and develop to be more humane and responsible individuals. The subject of mathematics as the main subject in the school must be able to answer the challenge that education value can be taught through mathematics learning. Math learning should be more empowered to support the personal development of students.
\end{abstract}

Keywords:

Character building; Mathematics value education

\begin{abstract}
Abstrak
Kegagalan pendidikan dapat menciptakan produk yang tidak lagi memiliki kepekaan hati nurani yang berlandaskan moralitas, sense of humanity, dan problem kemerosotan moral. Banyak sekali kejadian yang mengindikasikan semakin terkikisnya moral anak bangsa, seperti pergaulan bebas, kekerasan anak-anak dan remaja, kejahatan terhadap teman, pencurian remaja, kebiasaan menyontek, penyalahgunaan obat-obatan, dan sebagainya. Untuk itulah pendidikan harus kembali ke fitrahnya. Pendidikan yang tidak hanya berorientasi pada kecerdasan intelektual tetapi juga kecerdasan emosional. Setiap mata pelajaran yang diajarkan hendaknya dapat membantu anak untuk tumbuh dan berkembang menjadi pribadi-pribadi yang lebih bermanusiawi dan bertanggung jawab. Mata pelajaran matematika sebagai mata pelajaran pokok di sekolah harus mampu menjawab tantangan bahwa pendidikan nilai dapat diajarkan melalui pembelajaran matematika. Pembelajaran matematika harus lebih diberdayakan untuk mendukung pengembangan pribadi siswa.
\end{abstract}

Kata Kunci:

Pembentukan karakte; Pendidikan nilai Matematika

\section{A. PENDAHULUAN}

Dewasa ini, teknologi informasi dan komunikasi semakin maju seiring dengan berkembangnya ilmu pengetahuan dan teknologi. Kemajuan teknologi informasi dan komunikasi tersebut tentunya semakin membantu kita dalam melakukan aktivitas di kehidupan sehari-hari. Kemajuan teknologi memang sangat diperlukan demi memberikan kemudahan kepada masyarakat, setiap inovasi selalu diciptakan dengan tujuan untuk memberikan manfaat positif bagi kehidupan manusia. Namun tidak dipungkiri, di sisi lain teknologi mendatangkan berbagai efek negatif bagi masyarakat. Teknologi yang seharusnya merupakan alat ekstensi kemampuan diri akan mengakibatkan rusaknya karakter generasi muda bangsa ini jika disalahgunakan.

Jika diamati, sumber pemberitaan media cetak dan media elektronik akhir-akhir ini diramaikan oleh terjadinya kasus-kasus yang mengindikasikan bahwa karakter bangsa ini semakin terkikis. Banyak sekali masalah sosial terjadi yang diakibatkan rusaknya moral bangsa. Sebagai contohnya adalah maraknya angka kekerasan anak-anak dan remaja. Dari data Komisi Nasional Perlindungan Anak tercatat adanya peningkatan kasus kriminalitas yang dilakukan oleh anak di Indonesia. Jika pada tahun 2013 terdapat 730 kasus yang 
melibatkan anak sebagai perilaku kriminal. Angka tersebut meningkat pada tahun 2014 menjadi 1.851 kasus. Bahkan pada tahun 2013 sebanyak 16\% pelaku kriminalitas berusia dibawah 14 tahun. Sedangkan, pada tahun 2014 meningkat sebanyak 26\%. Sebuah data dari Komisi Perlindungan Anak Indonesia (KPAI) juga mengungkapkan bahwa jumlah anak yang berhadapan dengan hukum pada rentang bulan Januari hingga April 2016 sangat mengkhawatirkan, yaitu sebanyak 298 kasus. Angka ini mengalami peningkatan sebesar $15 \%$ dibandingkan tahun 2015 pada periode yang sama. KPAI juga mencatat jumlah kekerasan anak selalu meningkat setiap tahun.

Pada rentang waktu tahun 2011 hingga 2014 tercatat lebih dari 15.000 kasus kekerasan anak. Pada tahun 2010 terungkap 95 pelajar SD di Bekasi menggunakan narkotika dan obat-obatan terlarang. Sedangkan di Jakarta, 1 dari 1.350 anak usia SD terbukti menggunakan narkoba. Rusaknya moral anak indonesia juga terlihat dari kebiasaan mereka menghisap rokok. Berdasarkan data Komisi Nasional (Komnas) Perlindungan Anak pada rentang tahun 2008 hingga 2012 jumlah perokok anak dibawah umur 10 tahun di Indonesia mencapai 239.000 orang. Sedangkan jumlah perokok anak antara usia 10 hingga 14 tahun mencapai 1,2 juta orang. Fakta-fakta di atas merupakan segelintir contoh yang menunjukan ada yang salah dengan karakter anak Indonesia.

Terdapat sejumlah faktor yang menjadi penyebab lunturnya karakter anak bangsa diantaranya adalah fakta bahwa dunia anak yang secara umum suka meniru atau mengimitasi perilaku orang di sekitarnya seperti orang tua, lingkungan sosial masyarakat, dan sekolah. Di samping itu, tontonan-tontonan melalui televisi dan internet juga memberikan dampak yang besar pada karakter anak. Faktor penyebab lainnya adalah tersumbatnya saluran energi anak terutama di sekolah. Sekolah tidak lagi ramah terhadap pembentukan karakter anak karena kurikulum yang digunakan lebih banyak berorientasi pada kecerdasan intelektual. Sementara kecerdasan emosional tidak tersalurkan dengan baik. Penekanan terhadap pendidikan nilai sering terlupakan dalam proses pendidikan selama ini. Pendidikan yang diterapkan kurang menekankan adanya keseimbangan antara aspek spiritual dengan intelektual, sehingga produk pendidikan bukanlah manusia utuh yang memiliki karakter yang kuat, melainkan manusiamanusia yang individualis, materialis, dan pragmatis.

Di tengah perkembangan masyarakat yang semakin konsumtif dan materialistis dewasa ini, paradigma yang menempatkan pendidikan sebagai usaha untuk memperkuat karakter bangsa semakin terkikis. Justru yang seringkali mencuat ke permukaan adalah bahwa pendidikan untuk uang, atau pendidikan yang mampu menciptakan manusia "siap pakai". Kegagalan pendidikan yang paling fatal adalah ketika produk penddidikan tidak lagi memiliki kepekaan hati nurani yang berlandaskan moralitas, sense of humanity, dan problem kemerosotan moral yang semakin merebak. Pendidikan telah gagal dalam menanamkan nilai-nilai moral. Kehilangan moralitas menjadi sumbu hilangnya sendi-sendi masyarakat dewasa, mereka hanya membentuk peradaban yang sekarat yang entah sampai kapan dapat diatasi secara tuntas. Pendidikan yang seharusnya membuat manusia menjadi manusia mulia, justru seringkali tidak memanusiakan manusia.

Kepribadian manusia cenderung direduksi oleh sistem pendidikan yang ada. Pendidikan ternyata mengorbankan keutuhan, kurang seimbang antara belajar yang berpikir (kognitif) dan perilaku belajar yang merasa (afektif). Unsur integrasi cenderung semakin hilang, yang terjadi adalah disintegrasi. Padahal belajar tidak 
hanya berpikir. Sebab, ketika orang sedang belajar, maka orang tersebut melakukan berbagai macam kegiatan, seperti mengamati, membandingkan, meragukan, menyukai, dan berbagai macamnya.

Mencermati begitu pentingnya nilai-nilai moral diintegrasikan dalam pendidikan maka pendidikan harus segera kembali ke fitrahnya. Pendidikan harus mampu memanusiakan manusia dan menempatkan kemanusiaan pada derajat tertinggi. Pembelajaran yang dilaksanakan di sekolah seharusnya tidak hanya berorientasi pada kecerdasan intelektual tetapi juga kecerdasan emosional. Setiap mata pelajaran yang diajarkan hendaknya dapat membantu anak untuk tumbuh dan berkembang menjadi pribadi-pribadi yang lebih bermanusiawi, bertanggung jawab, berguna dan berpengaruh di dalam masyarakatnya. Masyarakat membutuhkan pribadi-pribadi yang handal dalam bidang akademis, keterampilan atau keahlian dan sekaligus memiliki watak atau keutamaan yang paling luhur.

Berdasarkan deskripsi di atas, maka masalah yang perlu diperjelas adalah apakah benar selama ini pembelajaran yang dilaksanakan di kelas gagal menumbuh kembangkan pendidikan nilai? Apakah pendidikan nilai dapat diintegrasikan pada semua mata pelajaran, termasuknya mata pelajaran matematika? Masalah tersebut selanjutnya dikaji melalui pertanyaan berikut. Pertama, bagaimanakah karakter bangsa Indonesia? Kedua, nilai-nilai apa saja yang dapat ditanamkan kepada anak dalam pembelajaran matematika?

\section{B. HASIL DAN PEMBAHASAN}

\section{Hakikat Karakter}

Karakter merupakan sifat yang melekat pada setiap manusia, sebagai faktor penentu seseorang untuk bersikap dan bertingkah laku, dengan dipengaruhi oleh situasi, kondisi, dan yang dirasakan dalam hati seseorang. Karakter lebih dekat dengan akhlak, yaitu spontanitas manusia dalam bersikap atau melakukan perbuatan yang menyatu dalam diri manusia sehingga ketika muncul tidak perlu dipikirkan lagi. Wynne berpendapat karakter merupakan nilai kebaikan dalam bentuk tingkah laku. Sementara itu Kamus Bahasa Indonesia mengartikan karakter sebagai tabiat; sifatsifat kejiwaan, akhlak atau budi pekerti yang membedakan seseorang dengan yang lain. Sedangkan Kemendiknas menyatakan karakter sebagai suatu moral excellence atau akhlak dibangun di atas berbagai kebajikan (virtues) yang pada gilirannya hanya memiliki makna ketika dilandasi atas nilai-nilai yang berlaku dalam budaya (bangsa).

Karakter bangsa sangat penting untuk membangun bangsa yang kuat dan bermartabat. Oleh karena itu, Kementerian Pendidikan mengembangkan 18 nilai dalam pendidikan karakter bangsa. Mulai tahun ajaran 2011, seluruh tingkat pendidikan di Indonesia harus mempersiapkan pendidikan berkarakter dalam proses pendidikannya. 18 nilai-nilai dalam pendidikan karakter bangsa menurut kementerian Pendidikan Nasional dan Kebudayaan adalah (1) Religius, (2) Jujur, adalah perilaku yang menunjukkan dirinya sebagai orang yang dapat dipercaya, konsisten terhadap ucapan dan tindakan sesuai dengan hati nurani. (3) Toleransi, (4) Disiplin, (5) Kerja keras, (6) Kreatif, (7) Mandiri, (8) Demokratis, (9) Rasa ingin tahu, (10) Semangat kebangsaan, (11) Cinta tanah air, (12) Menghargai prestasi, (13) Bersahabat/komunikatif, (14) Cinta damai, (15) Gemar membaca, (16) Peduli lingkungan, (17) Peduli sosial, dan (18) Tanggung jawab.

\section{Pendidikan Nilai dalam Matematika}

Secara rinci pendidikan nilai dapat mempunyai makna sendiri-sendiri, namun jika disatukan maka akan muncul beberapa defenisi tentang pendidikan nilai, ini berarti 
makna pendidikan nilai memicu banyak arti dan pengertian. Sastraprateja memberikan defenisi pendidikan nilai adalah penanaman dan pengembangan nilai-nilai pada diri seseorang. Sedangkan Mardimadja mendefenisikan pendidikan nilai sebagai bantuan terhadap peserta didik agar menyadari dan mengalami nilai-nilai serta menempatkannya secara integral dalam keseluruhan hidupnya. Kedua pakar ini sepakat bahwa konsep pendidikan nilai bukanlah kurikulum tersendiri yang diajarkan lewat beberapa mata pelajaran akan tetapi mencakup seluruh proses pendidikan. Jadi pendidikan nilai itu adalah ruh pendidikan itu sendiri, dimanapun diajarkan pendidikan nilai akan muncul dengan sendirinya.

Pendidikan nilai dapat dilakukan dalam proses pembelajaran di sekolah. Pembelajaran yang dimaksud adalah pembelajaran yang tidak hanya mampu mengantarkan siswa pada ketercapaian pengetahuan (domain kognitif) saja, tetapi juga ketercapaian pemahaman dan penerapan nilai-nilai. Pembelajaran nilai yang dirumuskan guru tidak serta merta dapat diterapkan ke semua mata pelajaran di sekolah. Hal ini berhubungan dengan karakteristik mata pelajaran masing-masing. Mata pelajaran yang ada dapat diberdayakan agar memberi kontribusi besar dalam pembelajaran nilai sehingga pada akhirnya pembelajaran nilai tidak hanya dibebankan pada mata pelajaran seperti pendidikan agama dan pendidikan kewarganegaraan saja, tetapi juga dapat dibebankan pada semua mata pelajaran.

Mata pelajaran matematika sebagai mata pelajaran pokok di sekolah harus mampu menjawab tantangan bahwa pendidikan nilai dapat diajarkan melalui pembelajaran matematika. Pembelajaran matematika harus lebih diberdayakan untuk mendukung pengembangan pribadi siswa. Pembelajaran matematika seharusnya tidak hanya diorientasikan pada penguasaan materi saja, tetapi perlu diubah terbuka menyentuh dimensi luas sehingga berkontribusi lebih besar dalam pendidikan nilai di sekolah.

Tantangan bagi guru matematika sekarang adalah bagaimana merumuskan dan melaksanakan pembelajaran matematika di kelas yang mengarah pada ketercapaian pendidikan nilai. Padahal banyak orang yang menganggap bahwa matematika merupakan disiplin ilmu yang miskin nilai. Sementara itu pendidikan nilai merupakan sebuah urgensi yang perlu diprioritaskan untuk diajarkan kepada siswa yang berada pada masa krisis identitas.

Banyak sekali nilai-nilai yang terdapat dalam matematika yang mungkin dapat diintegrasikan dalam setiap pembelajaran matematika. Nilai-nilai tersebut diantaranya adalah sebagai berikut:

\section{a. Memahami pentingnya kesepakatan}

Sadar atau tidak seseorang yang mempelajari matematika telah menggunakan kesepakatan-kesepakatan tertentu. Kesepakatan-kesepakatan itu terdapat dalam matematika yang rendah maupun yang tinggi, termasuk dalam matematika. Kesepakatan-kesepakatan itu dapat berupa simbol atau bilangan, istilah/konsep, definisi serta aksiomaaksiomanya. Contoh beberapa simbol, definisi dan konsep yang merupakan konvensi dalam matematika :

1) Simbol $\pi$ merupakan simbol yang mewakili $22 / 7$ atau 3,14 yang digunakan sebagai pengali untuk mencari luas dan keliling lingkaran.

2) Definisi trapesium (dalam materi segiempat) adalah segiempat yang memilki tepat sepasang sisi sejajar

3) Konsep bangun datar, contohnya segitiga, dapat digunakan untuk mengklasifikasikan bangun geometri lain sehingga dapat membedakan 
bangun datar yang merupakan contoh dan bukan contoh segitiga.

Kesepakatan-kesepakatan di atas tanpa disadari akan membentuk suatu konsep dalam pikiran siswa sehingga dapat mengklasifikasikan suatu permasalahan. Pola pikir demikian akan membantu siswa dalam memahami kesepakatan-kesepakatan yang ada di dalam masyarakat. Sebagai contoh, adanya aturan tentang tata tertib lalu lintas yang telah disepakati bersama dapat dipahami sebagai sebuah peraturan yang perlu dipatuhi. Dengan demikian nilai yang dapat dikembangkan siswa adalah memahami dan bertindak sesuai dengan kesepakatan yang berlaku di masyarakat.

\section{b. Menggunakan pola pikir deduktif}

Pola pikir deduktif merupakan pola pikir yang berusaha untuk menurunkan atau menerapkan pengertian atau sifat umum ke dalam sifat khusus. Suatu contoh di materi segiempat pola pikir ini dibutuhkan untuk menyederhanakan suatu informasi mengenai konsep-konsep dari keluarga segiempat seperti jajar genjang, persegi, belah ketupat, persegi panjang, trapezium, dan layang-layang. Jajar genjang dapat didefinisikan sebagai segiempat yang memiliki dua pasang sisi sejajar. Sementara itu, belah ketupat adalah segiempat yang kedua pasang sisinya sejajar dan panjang keempat sisinya sama. Dengan demikian, secara deduktif definisi belah ketupat dapat diturunkan dari jajar genjang yaitu jajar genjang yang keempat sisinya sama. Untuk persegi, yang merupakan jajar genjang juga (karena memiliki dua pasang sisi yang sejajar), juga dapat didefinisikan dari belah ketupat sehingga persegi adalah belah ketupat yang keempat sudutnya siku- siku.

Guru seharusnya membantu siswa untuk membangun konsep-konsep tentang segiempat sendiri dengan cara mengarahkan siswa dalam memilih cara yang sesederhana mungkin. Tujuannya adalah semakin sederhana informasi yang dilibatkan, maka semakin mudah memahami dan mengingatnya. Nilai yang dapat diambil dari pola berpikir deduktif ini adalah kelak siswa diharapkan mampu menyelesaikan permasalahan baik masalah pribadi maupun masalah kelompok dengan cara memikirkan cara yang paling sederhana untuk mendapatkan solusi yang terbaik.

\section{c. Mampu menyesuaikan diri dengan lingkungan}

Pembicaraan matematika sangat erat kaitannya dengan semesta. Simbolsimbol yang digunakan memiliki arti tersendiri tergantung semesta pembicaraannya. Misalkan pada materi persamaan linear satu variabel, kalimat terbuka $3+2 x=8$, akan menjadi kalimat tertutup jika variabel $\mathrm{x}$ digant dengan suatu unsur. Kalimat tertutup ini tidak selamanya akan bernilai benar jika $x$ diganti dengan 2,5. Jika yang dimaksud $x$ dalam kalimat ini adalah bilangan bulat, maka tentu tidak ada $x$ yang memenuhi. Hal ini berarti bila semesta yang ditetapkan tidak diperhatikan oleh siswa, sangat besar kemungkinan jawaban yang mereka berikin menjadi salah.

Nilai yang dapat diambil dari pembicaraan semesta dalam matematika ini adalah siswa seharusnya dapat menyesuaikan diri dengan lingkungan tempat mereka berpijak sesuai dengan peraturan yang berlaku di lingkungan itu. Sikap penyesuaian diri ke dalam lingkungan yang berbeda amat perlu dimiliki siswa. Implikasinya adalah seorang siswa perlu memperhatikan tempat dia berada sehingga mampu menata tingkah laku termasuk cara berbicaranya dengan baik sesuai dengan karakterisitik lingkungan tempat ia tinggal.

\section{d. Jujur dalam bertindak}

Pada materi persamaan linear satu peubah terdapat pengertian kalimat 
terbuka, yaitu kalimat yang belum diketahui nilai kebenarannya. Jika variabel dalam kalimat ini diganti dengan unsur lain, maka kalimat ini akan menjadi kalimat tertutup yang bernilai benar atau salah.

Sebagai contoh: $4+x=7, \quad x$ bilangan cacah. Kalimat tersebut menjadi kalimat tertutup jika $\mathrm{x}$ kita ganti dengan bilangan cacah. Jika $\mathrm{x}$ diganti dengan 3 maka akan menjadi kalimat benar. Tetapi jika $x$ diganti dengan selain 3 maka menjadi kalimat salah.

Dari contoh di atas bisa kita integrasikan nilai kejujuran pada diri siswa, yaitu pada persamaan linear dengan satu peubah yang memiliki penyelesaian, hanya ada satu jawaban yang menjadikan kalimat itu benar, dan tidak dapat dimanipulasi atau membohongi bilangan atau solusi tersebut. Misalkan kita mengganti $\mathrm{x}$ dengan bilangan 7 dan kita mengatakan pernyataan itu benar, secara matematika dapat dibuktikan bahwa pernyataan kita salah atau berbohong. Jadi nilai yang bisa diserap oleh siswa adalah untuk selalu mengatakan yang benar itu benar dan yang salah itu salah, atau dengan kata lain mereka harus selalu jujur dalam berbuat.

\section{e. Fleksibel dalam memecahkan suatu masalah}

Beberapa permasalahan dalam matematika memiliki beberapa metode pemnyelasaian. Contohnya permasalahan sistem persamaan linear dua variabel. Beberapa metode yang ditawarkan dalam mencari solusi dari sistem persamaan linear ini adalah metode eliminasi, substitusi, campuran substitusi-eliminasi, dan metode grafik. Metode-metode penyelesaian tersebut dipilih, tergantung pada karakteristik soal yang akan dipecahkan.

Jika dihubungkan dengan masalahmasalah yang dihadapi oleh siswa dalam kesehariannya, maka melalui pemecahan masalah pada materi sistem persamaan linear dua variabel, siswa diajarkan tentang keberagaman cara yang dapat digunakan dalam menyelesaikan suatu permasalahan. Hal ini berarti kekakuan dalam menggunakan sebuah metode penyelesaian masalah akan membuat siswa sulit dalam menemukan solusinya. Oleh karena itu, diperlukan sikap fleksibel dalam menghadapi sebuah masalah.

\section{f. Teliti dalam berbuat}

Ketelitian sangat dibutuhkan seorang siswa ketika mengerjakan soal matematika terutama soal matematika yang mempunyai cukup banyak informasi yang dilibatkan dan membutuhkan kejelian dalam proses penghitungnya. Jika langkah awal pengerjaan sudah salah, maka akan berakibat fatal terhadap langkah selanjutnya.

Jika nilai-nilai dari sikap teliti ini terus dipupuk, maka bukan tidak mungkin pada nantinya akan membentuk pribadi siswa yang selalu jeli dalam melihat titik- titik masalah dan berusaha memecahkan masalah itu dengan menggunakan variabel-variabel yang ada sehingga pada akhirnya dapat menemukan solusi terbaik dari suatu permasalahan.

\section{SIMPULAN}

Pembentukan karakter sangat penting, bahkan sangat mendesak, dan tidak bisa ditawar-tawar lagi. Hal ini cukup beralasan karena adanya krisis yang terus berkelanjutan melanda bangsa dan negara kita. Oleh karena itu, pendidikan harus kembali ke fitrahnya. Pendidikan yang memanusiakan manusia dan menempatkan kemanusiaan pada derajat tertinggi. Sehingga setiap mata pelajaran yang disampaikan ke anak haruslah diintegrasikan dengan pendidikan nilai, termasuk diantaranya mata pelajaran matematika. Ada banyak nilai-nilai yang dapat ditanamkan dalam matematika, diantaranya adalah memahami pentingnya 
kesepakatan, menggunakan pola pikir deduktif, mampu menyesuaikan diri dengan lingkungan, jujur dalam bertindak, fleksibel dalam memecahkan suatu masalah, dan teliti dalam berbuat.

\section{DAFTAR PUSTAKA}

Kamus Besar Bahasa Indonesia. Jakarta: Pusat Bahasa Departemen Pendidikan Nasional. 2008.

Komnas Perlindungan Anak. Data Komisi Nasional (Komnas) Perlindungan Anak menunjukkan jumlah perokok anak dibawah umur 10 tahun di Indonesia mencapai 239.000 orang. Diakses dari http://www.voaindonesia.com/a/peroko k-anak-di-bawah-10-tahun-diindonesia-capai-239000orang/727311.html, pada tanggal 09 November 2016. 2012

Komnas Perlindungan Anak."kasus kriminalitas anak meningkat pada tahun 2014". Diakses dari http://www.gresnews.com/berita/sosial/ 21041-kasus-kriminalitas-anakmeningkat-pada-2014/0/, pada tanggal 09 November 2016. 2015

KPAI. "Pelaku Kekerasan Terhadap Anak Tiap Tahun Meningkat" diakses dari http://www.kpai.go.id/berita/kpaipelaku-kekerasan-terhadap-anak-tiaptahun-meningkat/, pada tanggal 09 November 2016. 2015

Mulyana. Mengartikulasikan Pendidikan

Nilai. Bandung: Alfabeta. 2004.

Pusat Kurikulum. Pengembangan Pendidikan Budaya dan Karakter Bangsa. Jakarta: Balitbang, Kemdiknas. 2010.

Wardani. Pendidikan Nilai-nilai Budaya dan Karakter Bangsa dalam Pembelajaran Matematika di SMP. Yogyakarta: PPPPTK. 2011.
Zuhdi, D. Pendidikan Karakter Grand Design dan Nilai-nilai Target. Yogyakarta: UNY Press. 2009. 